\title{
Cultural Tourism in Georgia: Opportunities at Global and Local Levels
}

\section{ESJ Social Sciences}

\section{Tamar Koblianidze}

(Professor)

Georgian Technical University, Georgia

\section{Nino Sachaleli}

( $\mathrm{PhD}$ Candidate)

Grigol Robakidze University, Georgia

Submitted: 16 October 2020

Accepted: 01 December 2020

Published: 31 December 2020

Corresponding author:

Nino Sachaleli

DOI: 10.19044/esj.2020.v16n34p1

(c) Copyright 2020 Sachaleli N. \& Koblianidze T. Distributed under Creative Commons BY-NC-ND 4.0 OPEN ACCESS

\begin{abstract}
There is an opinion that culture and tourism have a symbolic relationship with each other. Art, dance, rituals, and legends are at risk of being forgotten by modern generations, but they can be revived by tourists who have an interest in the cultures of ancient countries such as Georgia. Monuments and cultural heritage can even be protected by foundations and organizations in the field of tourism and culture, which protect and popularize them and at the same time increase the number of visitors. Today, creativity and modern technologies are changing the connection between culture and tourism. This has made cultural tourism become more desirable and accessible. With the help of technologies, it is getting closer and closer to modern approaches than it was in the past. The paper outlines the challenges of developing sustainable cultural tourism in Georgia. Statistics on state documents, projects, and cultural tours organized by local tour companies was also discussed. They employed both qualitative and quantitative research methodologies which showed that besides pandemic, there is a demand for cultural tourism. Georgian tour companies are offering a wide range of cultural tours and tourists have interest in it. Its full potential has not been harnessed and the main attention is paid to UNESCO heritage. The development of cultural tourism poses challenges (e.g., implementation of digital technologies, quality control mechanisms) for Georgia to become more recognizable within this kind of synergy, which is called the fusion of culture and tourism.
\end{abstract}

Keywords: Cultural heritage, tourism, EU Cultural Routes, Georgian tourism, UNESCO heritage 


\section{Introduction}

Culture and tourism were always connected with each other. Cultural heritage and cultural events are the main motivators for travelling, while travelling creates culture itself. The relationship between tourism and culture became obvious during the last years when a different form of travelling called cultural tourism was developed. Cultural tourism, as a social phenomenon, and the subject of studies became popular after the Second World War, when people started moving from one country to another for leisure and cognition. The economic growth began from 1960-1970 and during this period, international tourism and cultural exchange started between the nations. Since 1980, the main places which were attracting tourists were identified and have been labeled as cultural sights. The interest in cultural tourism was caused by the "Heritage boom" (Hewison, 1987). This showed the growth of international and domestic travelling and the identification of cultural tourism as a "good" form of tourism that would stimulate the economy and help conserve culture (Richards, 2001).

The beginning of early 1990s can be considered as the period of cultural tourism transformation, which involved the travel of elite type tourists. However, cultural tourism has to face other opportunities and challenges such as "mass tourism". Consequently, cultural tourism became a phenomenon for many places of interest and this has led to cultural heritage tourism, art tourism, gastronomic tourism, creative tourism, etc. The expanded concept of cultural tourism has certainly contributed to the development of cultural tourism. Nonetheless, from 2013, cultural tourism has faced another challenge and problem. Also cultural places of interest are overcrowded and a new concept known as "over-tourism" has appeared. For several cases, after its increased interest, it became necessary to defend cultural objects. In some cases, the conservation problem is also important.

\section{Materials and Methods}

The research was conducted using materials provided by research papers, strategies, literature reviews, official statistics (analyzing statistics regarding Georgia as a cultural tourism destination), as well as books and internet resources of Georgian and foreign scientists (international and state organizations). Content analysis method was used to study the potential of cultural tourism, the current situation, and the cultural tours of Georgian tour companies (chosen according to their activities). An analysis of commercial websites of tour companies was then carried out. Hence, this gave rise to an opportunity to discuss the potential of cultural tourism development at the global level on a long-term period. Furthermore, quantitative research method (which interviewed 200 local tourists) was used to investigate the opportunity of developing cultural tourism at the local level. Thus, this was carried out 
based on the hypothesis that due to the pandemic, there would be increased demand for cultural tourism between local tourists. Also, the potential of cultural tourism development in Georgia is discussed according to the recommendations from the European Council Working Plan for Culture and Sustainable Cultural Tourism.

\section{Main Text}

Cultural tourism is often used as a general term, which describes the lifestyle of local people, art, traditions, and festivals. This kind of concept allows cultural tourism to build strong competitiveness and develop cultural characteristics of the country on an international level. There are two types of cultural tourism. The first is cultural tourism with tangible components such as cultural heritage monuments, museums, churches, galleries, etc. The second is culture with intangible components, which involves attending various festivals, enjoying local food and wine, attending cultural events, etc. Cultural tourism involves travelling to gain new experiences and sometimes participate in a vanishing lifestyle that lies within human memory (Goeldner \& Ritchie, 2009).

Cultural tourism is a type of tourism activity in which the visitor's essential motivation is to learn, discover, experience, and consume the tangible and intangible cultural attractions/products in a tourism destination. These attractions/products are related to a set of distinctive material, intellectual, spiritual, and emotional features of a society that encompasses arts and architecture, historical and cultural heritage, culinary heritage, literature, music, creative industries, the living cultures with their lifestyles, value systems, beliefs, and traditions (Richards, 2018). Figure 1 shows the cultural tourism diversification forms, which consists of various types of activities. 


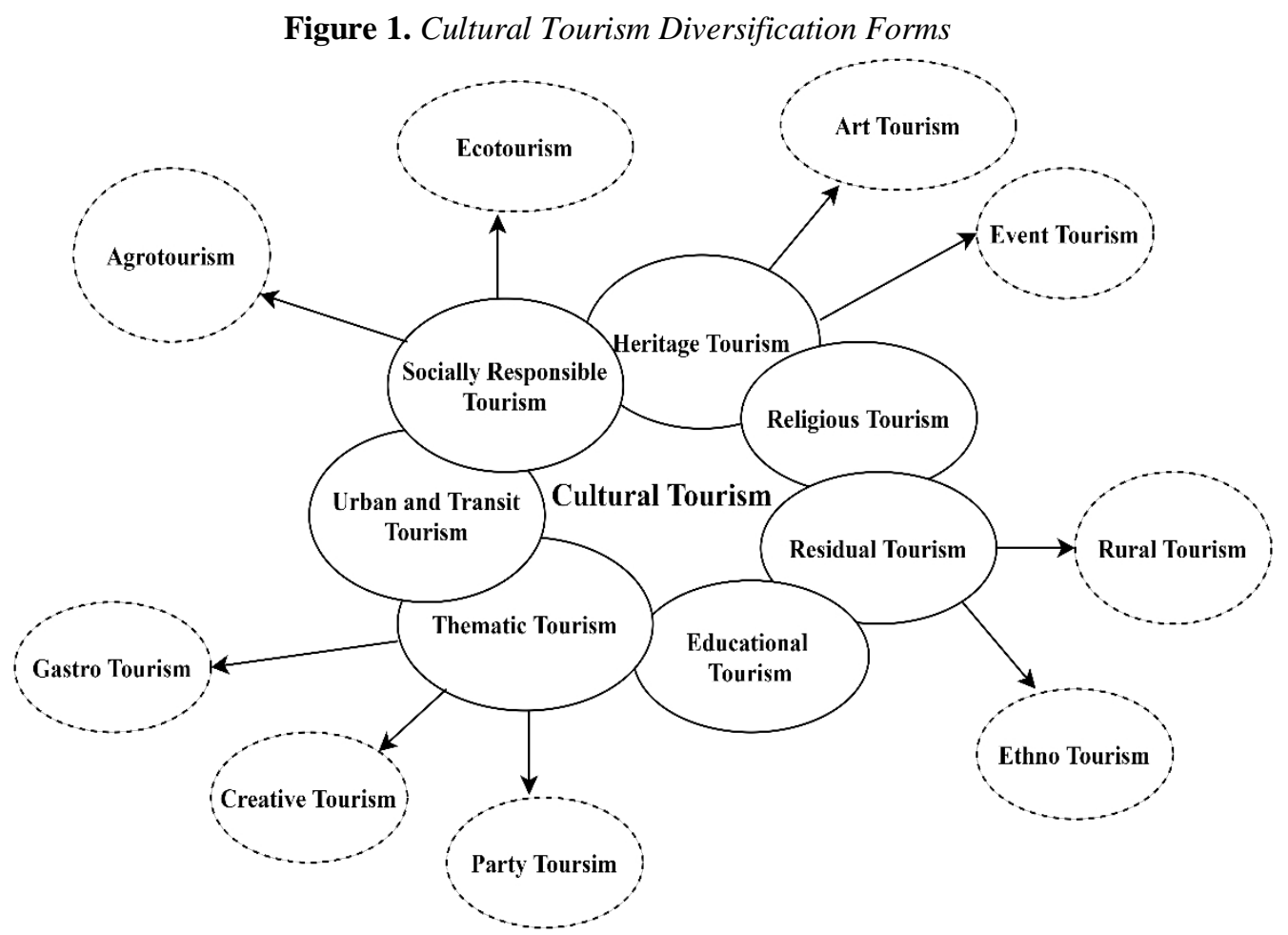

Note. Adopted from (Vujović, 2018)

Smith explains cultural tourism as a form of travelling when a person or a group of people are in search of a place where they can be excited by the unique culture of other people and respect the different cultural values so as to develop friendly relationships with other communities (Smith, 2003). The development of cultural tourism has played an important role in raising social awareness of cultural heritage (Jittangwattana, 2005). However, there were different opinions regarding the essence of cultural tourism. The main idea of cultural tourism is to show tourists the intercultural differences, language, traditions, and get the experience they expected before travelling. Cultural tourism covers all aspects of travelling whereby people learn about each other's ways of life and thought patterns. Tourism is thus an important means of promoting cultural relations and international cooperation. Conversely, the development of cultural factors within a nation is a means of enhancing resources to attract visitors. In many countries, tourism can be linked with a "cultural relations" policy. It is used to promote not only knowledge and understanding, but also a favorable image of the nation among foreigners in the travel market. The channels through which a country presents itself to tourists can be considered as its cultural factors. These include the entertainment, food, drink, hospitality, architecture, manufactured and 
handcrafted products of a country, and all other characteristics of a nation's way of life (Goeldner \& Ritchie, 2009).

\section{Research Findings}

According to the study, developing cultural tourism can bring about many benefits to all including the people, regional development, country, and future generations. Figure 2 shows the benefits of developing cultural tourism.

Figure 2. Benefits of Cultural Tourism Development

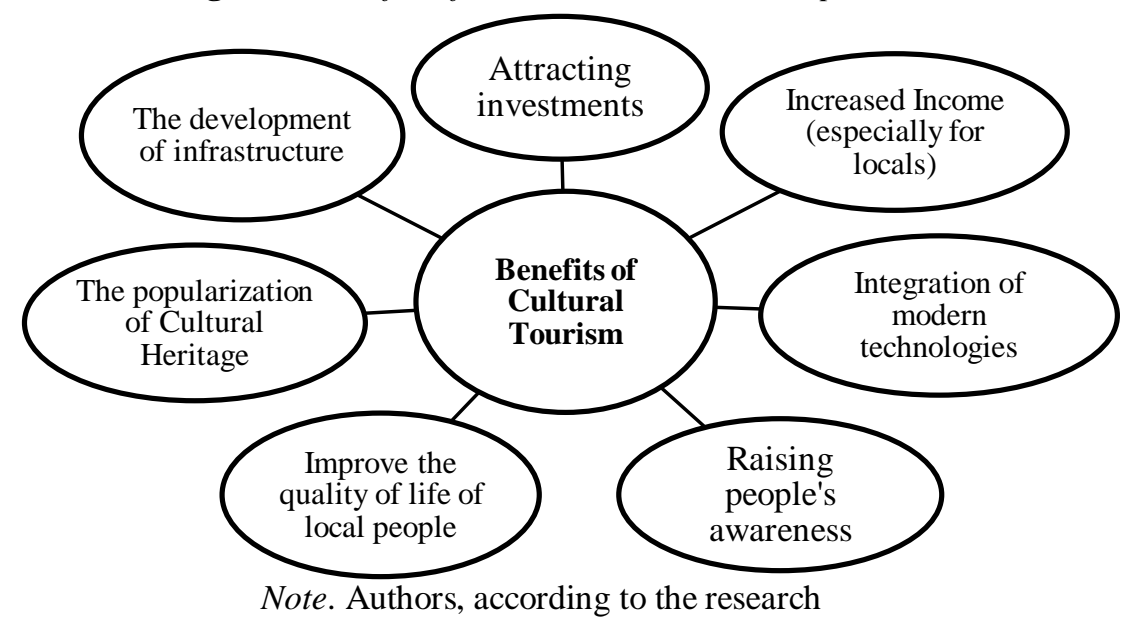

Cultural tourism development can also result in negative and positive social-cultural impacts. These impacts are shown in Table 1.

Table 1. Social-Cultural Impacts of Cultural Tourism Development

\begin{tabular}{|l|l|}
\hline Positive & Negative \\
\hline$\checkmark$ Promotion of the country's cultural values; & $\checkmark$ Unwanted lifestyle changes; \\
$\checkmark$ Positive changes in values and behaviors; & $\checkmark$ Influences on language and culture; \\
$\checkmark$ Improves life quality; & $\checkmark$ Negative influences on values and customs; \\
$\checkmark$ Development of educational programs (study the art & $\checkmark$ Changing the location of the local population to \\
of meeting guests/hospitality); & arrange the necessary infrastructure for tourism; \\
$\checkmark$ Increased demand for historical and cultural value; & $\checkmark$ Migration of local People; \\
$\checkmark$ Cultural exchange; & \\
$\checkmark$ Adopts responsible behavior; & \\
\hline
\end{tabular}

Note. Authors, according to the research

Table 1 outlines the need for cultural tourism development to be planned carefully on behalf of the sustainable development standards so as to get rid of negative impacts, which will cause serious problems.

The changing nature of cultural tourism was recently brought into focus by a UNWTO Report on Tourism and Culture Synergies (UNWTO, 2018). This included online surveys covering $43 \%$ of UNWTO member states as well as 61 international experts and academics in the field. This study 
confirmed the importance of cultural tourism. Also, $89 \%$ of national tourism administrations indicated cultural tourism as a part of their tourism policy. Almost all member states included tangible heritage and intangible heritage in their definition of cultural tourism, and over $80 \%$ also included contemporary culture (e.g., film, performing arts, design, fashion, new media, etc.). Tangible heritage was rated as the most important element of cultural tourism. This was followed by intangible heritage and contemporary culture.

Sustainable Cultural Tourism was highlighted as one amongst the ten initiatives for the European Year of Cultural Heritage, and it has provided an unprecedented opportunity to explore the relationship between cultural heritage and cultural tourism. According to the document, "Sustainable Cultural Tourism" is the integrated management of cultural heritage and tourism activities in conjunction with the local community creating social, environmental, and economic benefits for all stakeholders to achieve tangible and intangible cultural heritage conservation and sustainable tourism development (Sustainable Cultural Tourism European Comission, 2018). The document contains recommendations for tourism associations, operators, developers, entrepreneurs, and tourists (consumers). The recommendations are also important for Georgia, even though it is not a member of the EU. Thus, Table 2 and Table 3 below show the recommendations given to Georgia and their response.

Table 2. Recommendations from Council Work Plan for Culture Tourism associations, operators, developers, and entrepreneurs

\begin{tabular}{|l|c|}
\hline \multicolumn{1}{|c|}{ Recommendation } & Georgia \\
\hline $\begin{array}{l}\text { Invest in long-term economic and entrepreneurial development plans that } \\
\text { include sustainability and social responsibility as part of the business strategy. }\end{array}$ & Yes \\
\hline $\begin{array}{l}\text { Consult with local communities to develop and agree on high quality tourism } \\
\text { offers, experiences, and products based on authentic cultural heritage. }\end{array}$ & No \\
\hline $\begin{array}{l}\text { Provide guidelines and training for responsible tourism for both tourism } \\
\text { practitioners (tour operators) and consumers (individual travelers). }\end{array}$ & $\begin{array}{c}\text { Not } \\
\text { Completely }\end{array}$ \\
\hline Support start-up clusters for cultural tourism entrepreneurship. & $\begin{array}{c}\text { Not } \\
\text { Completely }\end{array}$ \\
\hline $\begin{array}{l}\text { Avail of existing applications (e.g., United Nations Environmental) or develop } \\
\text { new online toolkits and digital applications for measuring visitor impact. }\end{array}$ & $\begin{array}{c}\text { Not } \\
\text { Completely }\end{array}$ \\
\hline $\begin{array}{l}\text { Promote new emerging destinations and facilitate integrated marketing with the } \\
\text { support of local communities. }\end{array}$ & Yes \\
\hline $\begin{array}{l}\text { Develop pricing structures that encourage longer stays and visits in the low } \\
\text { season. }\end{array}$ & Yes \\
\hline $\begin{array}{l}\text { Publish tourism data to enable evaluation, monitoring, and mapping of the } \\
\text { variable dynamics in the field by local and national governments. }\end{array}$ & Yes \\
\hline Support local businesses and favor local products to encourage unique offerings. & Yes \\
\hline $\begin{array}{l}\text { Ensure a positive working environment by creating permanent employment or } \\
\text { long-term employment through the low season. }\end{array}$ & No \\
\hline
\end{tabular}

Note. Authors, according to the EU Member States Working plan (Sustainable Cultural Tourism European Comission, 2018) 


\section{Invest in Long-term Economic and Entrepreneurial Development Plans}

According to the study, Georgia has the greatest potential for developing Sustainable Cultural Tourism. The National Tourism Administration of Georgia has developed the document "Georgian Tourism Strategy 2025", which aims to create a guide that will contribute tourism to sustainable development. This will increase revenues and the importance of the sector. According to the strategy, the responsibility of the Georgian government is to develop and implement a plan that will turn rich natural and cultural resources into a world-class tourism product and also create an opportunity to make unique impressions. According to the strategy in 2025, Georgia will be well known as a premier year-round, high-quality tourism destination, centered on its unique cultural and natural heritage, world-class customer service, and timeless tradition of hospitality (Tourism Strategy Reform Overview, n.d.).

The Georgia Tourism Strategy from 2015-2025 gives strong importance to cultural heritage and cultural tourism, which is expressed by the first two objectives. The first objective hints on the need to respect, to enhance, and protect Georgia's natural and cultural heritage. The second objective focuses on unique and authentic visitor experiences centered on those natural and cultural assets. Furthermore, it highlights the importance of developing and promoting routes and trails as part of tourism development (Szivas, 2019).

The National Tourism Administration supports cultural tourism, takes part in various ceremonies, and organizes marketing campaigns. As a result, Tbilisi was nominated as the "Best Cultural City" of 2020 in a competition held in Berlin. The capital of Georgia won the LCD (Leading Culture Destinations) Berlin Awards at a joint ceremony of the Global Cultural Travel Network and Visit to Berlin. Tbilisi's competitors were various world-famous tourist cities. 50 cultural destinations from 28 countries were also represented at the 6th LCD Awards Ceremony (Georgian National Tourism Administration, 2020).

Another important document is the Culture Strategy 2025, which represents the long-term strategic document of the Government of Georgia. This determines state vision, goals, and perspectives considering different challenges faced by the culture sector in Georgia.

The Ministry of Culture and Monument Protection of Georgia elaborated the document in cooperation with other government agencies and with the active participation of the general public. The strategy creation process was supported by EU institutions. Furthermore, the Council of Europe and the European Union evaluated the cooperation positively. The strategy has fundamental principles such as publicity, civil-society engagement, and transparency. It also cooperates with governmental representatives, nongovernmental organizations, international organizations, professionals, 
business, and educational institutions to reform institutional and legislative actions in order to develop creative industries in the cultural sector (Creative Georgia Culture Strategy of Georgia 2025, n.d.).

\section{Promote New Emerging Destinations and Facilitate Integrated Marketing with the Support of Local Communities}

Project "Zrda" (USAID) supports tourism development in the regions, promotes the development of new tourism products, new tourism facilities and landmarks, and improves the quality standards of the parties involved in the tourism sector through a comprehensive approach. To promote tourism development, the main regions of "Zrda" are Samtskhe-Javakheti, Samegrelo, and Tusheti. However, the promotion of family-type hotels in the target regions remains one of the main directions of the project. "Zrda", in cooperation with the National Tourism Administration of Georgia and the public and private sectors in the regions, facilitates the development of a tourism development model in the Samtskhe-Javakheti and Samegrelo regions. The model is focused on agro, eco, cultural, and adventure tourism development and aims to improve coordination and cooperation between stakeholders to better demonstrate the tourism potential of these regions.

\section{Provide Guidelines and Training for Responsible Tourism for both Tourism Practitioners (tour operators) and Consumers (individual travelers)}

The National Tourism Agency organizes training programs for legal entities and individuals representing the tourism industry. The training covers the subjects such as hotel business/service skills, hotel sales and revenue management, strategic approaches in the service industry, managerial management skills, managing problem situations, wine guide, adventure guide Skills, introduction and development of services for people with disabilities, first aid, ecotourism product and offer, marketing and sales, and management of international booking platforms (Training courses, National Tourism Administration., n.d.). In 2018, a tour company established a "Tourism Organization", which offers various trainings for tourism practitioners (Tourism Organization, n.d.). "Academic Press of Georgia", with the support of the Ministry of Education, Culture and Sports of Georgia, and "Creative Georgia" is starting the project: "Let's talk about cultural heritage". The project is for pupils from 5th to 8th form, and it aims to raise the awareness of cultural heritage among the youth (Academic Press of Georgia, n.d.). 


\section{Develop Pricing Structures that Encourage Longer Stays and Visits in the Low Season}

Discount Week is an event that includes discounted hotel services for domestic and international tourists in different regions of Georgia. It aims to popularize the region and encourage domestic tourism. The project will also help tourist facilities attract visitors. At the initiative of the Georgian National Tourism Administration ("Administration"), which is part of the Ministry of Economy and Sustainable Development of Georgia, a discount week ("Project") is planned to promote tourist attractions and tourism product development. At this stage, the expression of interest is announced for the selection of tourist facilities in the mountain resorts of Georgia (Discount Week National Tourism Administration, n.d.).

\section{Publish Tourism Data to Enable Evaluation, Monitoring, and Mapping of the Variable Dynamics in the Field by Local and National Governments}

The National Tourism Administration and the National Statistics Office of Georgia publish statistics monthly, which provides information about the dynamics of tourists, their interests, nationalities, etc. However, it needs to be more informative because it does not give information about local tourists and their interests as well as their expenses. Unfortunately, in Georgia, there are no organizations at the local level that carry out the researches and studies of tourism in regions.

\section{Support Local Businesses and Favor Local Products to Encourage Unique Offerings}

The Program "Produce in Georgia" Supports micro and small entrepreneurship, tourism-related services, and agricultural secondary production through access to finance and technical support. The minimum loan/lease amount is GEL 50,000 and the maximum is GEL 10,000,000 (Loan and Leasing Co-financing Program, Government your partner, n.d.). Local businesses are also supported by banks that offer "cheap loans" to provide assistance to the tourism industry.

Table 3. Recommendations from the Council Work Plan for Tourists (consumers)

\begin{tabular}{|l|c|}
\hline \multicolumn{1}{|c|}{ Recommendation } & Georgia \\
\hline Adopt responsible behavior both as a traveler and as a consumer. & No \\
\hline $\begin{array}{l}\text { Be conscious of "impact" and "ecological footprint" and use online toolkits and applications to } \\
\text { measure impact. }\end{array}$ & No \\
\hline Be conscious of the use of natural resources and follow any special instructions. & No \\
\hline Respect the local community and engage in the area's history, tradition, and culture. & Yes \\
\hline Avail of local produce, creative industries, goods and services to stimulate the local economy. & Yes \\
\hline
\end{tabular}

Note. Authors, according to EU Member States Working plan (Sustainable Cultural

Tourism. European Comission, 2018) 
As seen in Table 3, adopting responsible behavior both as a traveler and as a consumer is important for tourists and local people. Nowadays, vandal acts still exists when travelers damage cultural heritage. Therefore, adopting responsible behavior between the local people and Georgian tourists is important. During the research, it has also been hypothesized that people from different countries (e.g., developed countries, the EU, and post-soviet states) behave themselves in different manners, while people from developed countries and the EU appear to be the best socially responsible travelers. This case appears to be the other subject of the research and can be done in a separate article.

Furthermore, in regard to impacts measurements, Georgia still does not have implemented toolkits and applications to measure the impact. However, it is very important because mass tourism and over tourism can harm cultural heritage. Thus, it becomes impossible to save them for future generations. The development of mass tourism is not considered to be a good solution for economic development. Tourist destinations are also doing more about sustainability, environmental protection, and cultural heritage preservation (Kotollaku \& Margariti, 2015).

Local people in Georgia also respect their traditions and culture. Nonetheless, the main problem for them appears to be the low level of knowing modern technologies and the knowledge on how to make these unique cultural products more profitable. Local handmade crafts which are very expensive and attract the attention of tourists can be sold on the internet. They can also create clusters and sell local handicrafts with one brand and include master classes in the cultural tours, which will help cultural tourism to be more interactive with locals.

In addition, the European crafts sector combines tradition, heritage, culture, skill, and design. Craft encompasses a wide range of disciplines that reflects the diversity of European cultural identity.

In economic terms, the crafts industry is characterized by small entrepreneurial businesses that provide viable, sustainable employment in cities, towns, villages, and remote rural regions across the EU. Within this year, beginning from July, the new website craftingeurope.com was created and this is where handicrafts were sold. Supported by Creative Europe, the "Crafting Europe" project was inspired by the need to build capacity within the crafts sector across Europe. It is a partnership between nine (9) expert organizations across Europe. A key focus of this project is to enhance new skills and improve the employability of emerging and current professionals in the craft sector (Crafting Europe, 2020). Also, Georgian Arts and Culture Center (GACC) is the Georgian leading cultural NGO dedicated to preserve, develop, and promote Georgian Arts and Culture. Georgian Arts and Culture Center has a lot of projects. It helps to facilitate international exhibitions of 
the Georgian cultural gifts as well as to develop the local market within Georgia. The GACC regularly participates in International Gift and Craft Fairs to increase sales of Georgian goods and acts as an exporter of Georgian crafts products to international crafts markets (Gaccgeorgia, n.d.).

The fact that Georgia has a huge potential to develop Culture Tourism was also mentioned by The Council of Europe Cultural Routes. Also, Georgia is a part of their Routes and the Georgian government has also certified cultural routes. A mobile application was also created, which helps tourists to organize tours.

Cultural Routes of the Council of Europe with Georgia include the following tours: European Route of Jewish Heritage, Iter Vitis Route, Prehistoric Rock Art Trails, and European Route of Historic Thermal Towns.

Georgian Certified Cultural Routes: "St. Andrew's Path" - a pilgrimage route, the main theme of which is an excursion-pilgrimage (St. Andrew's Path, Cultural Routes of Georgia). "From Capital to Capital" - The two most important cities in the history of Georgia is Mtskheta and Tbilisi (From Capital to Capital, Cultural Routes of Georgia). "German Settlements" - The certified Route of German Settlements and Architectural Heritage in Georgia aims to promote, preserve, protect, and sustain the development of the German settlements in Georgia (German Settlements, Cultural Routes of Georgia). "Following Alexandre Dumas" - The Route is guided by Al. Duma's novel "The Caucasus", which was written by the famous writer during his journey in the Caucasus region. Thus, the one who will follow the writer's footsteps will discover local traditions, customs, and cultural heritage. The Route also implies cooperation with neighboring countries (Following Alexandre Dumas, Cultural Routes of Georgia).

Cultural relations between the Georgian cultural sector and its counterparts in the EU have intensified after the EU Association Agreement in 2014. Georgia is a member of the Steering Committee for Culture, Heritage, and Landscape of the Council of Europe. Georgia has ratified Council of Europe Conventions and the 2005 UNESCO Convention on the Protection and Promotion of the Diversity of Cultural Expressions in 2008. In 2015, Georgia joined the Creative Europe Program. Several cultural projects and researches have been supported by the Council of Europe, EU ENP, and Eastern Partnership Culture Programs (Szivas, 2019).

Subsequently, Georgian monuments are also listed in the UNESCO cultural heritage list (Gelati Monastery, Historical Monuments of Mtskheta and Upper Svaneti) (UNESCO, n.d.). In addition, tour companies are using these facts and they include these cultural heritages in their tours and mention it. Nevertheless, no information has been given about Europa Nostra, where for example Heritage Crafts Initiative is the Winner of the EU Prize for Cultural Heritage / Europa Nostra Award 2017 (Europa Nostra, Heritage 
Crafts Initiative for Georgia, n.d.). Also, the fortified Settlement of Mutso, which in 2019 on European Heritage Awards / Europa Nostra Awards, won the Public Choice Award (Europa Nostra, European Heritage Awards Ceremony, 2019, n.d.)

The Convention for the Safeguarding of Intangible Cultural Heritage established a Representative List to ensure better visibility of the Intangible Cultural Heritage of Humanity, enhance its importance, and promote international dialogue in regard to cultural diversity. Four Georgian elements were inscribed on the aforementioned list: (1) Georgian polyphonic singing was recognized by UNESCO as a Human masterpiece of Oral and Intangible Heritage in 2001. After the accession of Georgia to the Convention for Safeguarding of Intangible Heritage, Georgian polyphonic singing was inscribed on its Representative List in 2008. (2) The Ancient Georgian traditional Qvevri wine-making method has been on the list since 2013. (3) The living culture of the three writing systems of the Georgian alphabet has also been on the list since 2016. (4) "Chidaoba", wrestling in Georgia is on the list since 2018 (Intangible Cultural Heritage, n.d.). Thus, Georgian tour companies also have an opportunity to plan cultural events with these intangible heritages. This makes Georgia world famous and attract the attraction of tourists.

Furthermore, there are 43 Intangible Cultural Heritage Monuments, 4221 movable listed properties, 7577 immovable listed properties, 3 of international significance (World Heritage Properties), and 986 of national significance in Georgia (Cultural Heritage Policy, Council of Europe, n.d.).

Cheryl Hargrove (Hargrove, 2014) in the report, Attracting visitors and their spending, opined that the cultural district planning process must consider the following questions as to the viability of attracting and hosting tourists. Therefore, it will be important to answer these questions using a case study of Georgia.

Table 4. Questions while planning cultural tourism (in the case of Georgia)

\begin{tabular}{|c|c|}
\hline Question & Answer \\
\hline $\begin{array}{l}\text { How open is the destination for } \\
\text { hosting tourists from out-of- } \\
\text { town (hospitality)? }\end{array}$ & $\begin{array}{l}\text { Georgia is an open country for tourists and its hospitality is } \\
\text { world known. Tourists often want to arrive back in Georgia, } \\
\text { after having experienced a warm welcome and friendly } \\
\text { relationship. }\end{array}$ \\
\hline $\begin{array}{l}\text { Is "culture" a priority or } \\
\text { integral part of the destination's } \\
\text { economic development and } \\
\text { tourism strategy? }\end{array}$ & $\begin{array}{l}\text { Culture is a priority and it can be confirmed by the strategies, } \\
\text { which are already discussed in the article. }\end{array}$ \\
\hline $\begin{array}{l}\text { Is the DMO (destination } \\
\text { marketing organizations) } \\
\text { receptive to recognizing cultural } \\
\text { districts as part of their } \\
\text { destination brand? }\end{array}$ & $\begin{array}{l}\text { Destination marketing organizations are being created in } \\
\text { Georgia. Georgian National Tourism administration together } \\
\text { with USAID/ZRDA has already established destination } \\
\text { management organizations (DMOs) in Svaneti, Samegrelo, } \\
\text { Samtskhe-Javakheti, Kakheti, and Imereti. }\end{array}$ \\
\hline
\end{tabular}




\begin{tabular}{|c|c|}
\hline $\begin{array}{l}\text { Are current visitors interested in } \\
\text { cultural activities and } \\
\text { experiences? }\end{array}$ & $\begin{array}{l}\text { Current visitors are really interested in cultural activities and } \\
\text { this fact was also confirmed by the research which was done } \\
\text { on behalf of the article. The overviewed statistics also show } \\
\text { the interest in cultural tourism in } 2018-2019 \text {. }\end{array}$ \\
\hline $\begin{array}{l}\text { Does the proposed cultural } \\
\text { district complement or compete } \\
\text { with other attractions, activities, } \\
\text { and experiences in the } \\
\text { destination? }\end{array}$ & $\begin{array}{l}\text { Georgia has a huge opportunity to develop cultural tourism } \\
\text { and offer certain tours to tourists where natural resources and } \\
\text { balneological resources can be combined. To be original, } \\
\text { authentic, and individual are some of the main differences that } \\
\text { differentiate Georgia from other countries. For example, in } \\
\text { Tusheti, the cultural tour can be combined with a trip to } \\
\text { Tusheti Protected Areas, which has a unique nature and } \\
\text { biodiversity. }\end{array}$ \\
\hline $\begin{array}{l}\text { What activities or experiences in } \\
\text { the cultural district are not } \\
\text { currently available in the } \\
\text { destination and will appeal to } \\
\text { tourists? }\end{array}$ & $\begin{array}{l}\text { There is no calendar of local festivals in regions, which would } \\
\text { allow tourists to arrive and attend. There are no organized } \\
\text { master classes for local handicrafts or local dishes. All these } \\
\text { need to be well discussed and planned. It is very important } \\
\text { because the regions have such traditions and celebrations, } \\
\text { which tourists cannot see anywhere around the world. }\end{array}$ \\
\hline $\begin{array}{l}\text { How does this cultural district } \\
\text { compare to other cultural } \\
\text { districts in competitive } \\
\text { destinations? }\end{array}$ & $\begin{array}{l}\text { Georgia has an opportunity to develop cultural tourism in } \\
\text { almost every region because they all have cultural heritage, } \\
\text { monuments, museums, and traditions which differs one } \\
\text { district from another. The main challenge for the regions } \\
\text { appears to be tourists' interests, distance and infrastructure, } \\
\text { which makes travelling more desirable. }\end{array}$ \\
\hline $\begin{array}{l}\text { Can the cultural district } \\
\text { accomplish, satisfy, or } \\
\text { contribute to the realization of } \\
\text { most or all of these criteria? }\end{array}$ & $\begin{array}{l}\text { Cultural districts in Georgia also have the possibilities to } \\
\text { satisfy tourists, accomplish and contribute to the realization of } \\
\text { most or all of the criteria. However, the main challenges for } \\
\text { our country centers on standards and the sustainable } \\
\text { development of tourism. Since Georgia is a developing } \\
\text { country, it is not facing over-tourism or mass tourism } \\
\text { problems but gains more tourists' interest. }\end{array}$ \\
\hline
\end{tabular}

After the content analysis of Georgian tour companies' websites (5 tour companies), the research highlighted that Georgia has a huge potential to organize various types of cultural tours, with different kind of cultural elements. In addition, tour companies offer mostly the same type of tours and they do not use the potential fully. The offered tours do not include festivals or concerts and it can be included on demand. On the other hand, tourists can buy tickets on their own but the same websites do not give these possibilities. Price range (per day) is about 390-600 Gel and the number of days (3-7 days) depends on the tour. It includes a full package and the price is changeable according to the accommodation. Tours also offer travelling to neighboring countries. Table 5 gives detailed information about some cultural tours of the chosen tour companies. These companies were chosen because while doing a market study, they appeared to be among the most popular tour companies in Georgia. 
December 2020 edition Vol.16, No.34

Table 5. Cultural Tours of Georgian Tour Companies

\begin{tabular}{|c|c|c|c|}
\hline $\begin{array}{l}\text { The name of the } \\
\text { tour company }\end{array}$ & $\begin{array}{l}\text { Language } \\
\text { of the } \\
\text { website }\end{array}$ & Details about the offered tours & Days \\
\hline \multirow{4}{*}{$\begin{array}{l}\text { Tour operator } \\
\text { "Caucasus Travel" } \\
\text { http://www.caucasust } \\
\text { ravel.com }\end{array}$} & \multirow{4}{*}{$\begin{array}{l}\text { English, } \\
\text { Russian, } \\
\text { German, } \\
\text { French, } \\
\text { Italian, } \\
\text { Chinese, } \\
\text { Spanish }\end{array}$} & $\begin{array}{l}\text { Discover Georgia (Tbilisi, Mtskheta, Gori, Kutaisi, } \\
\text { Signagi) } \\
\text { Historical cultural monuments: Svetitskhoveli, Jvari, } \\
\text { Ananuri arch complex, Gergeti Trinity, Uplistsikhe, } \\
\text { Davit Gareji. }\end{array}$ & 8 days \\
\hline & & $\begin{array}{l}\text { The spirit of Georgia (Tbilisi, Signagi, Mtskheta, } \\
\text { Gudauri, Kazbegi, Gori, Bakuriani, Kutaisi, Batumi). } \\
\text { Cultural monuments: Davit Gareji, Svetitskhoveli, } \\
\text { Jvari, Ananuri Arch. Complex, Gergeti Trinity, } \\
\text { Uplistsikhe, Vardzia, Gelati, Bagrati. }\end{array}$ & 13 days \\
\hline & & $\begin{array}{l}\text { Land of the Golden Fleece (Tbilisi, Mtskheta, Gori, } \\
\text { Kutaisi, Zugdidi, Mestia, Batumi). } \\
\text { Cultural monuments: Svetitskhoveli, Jvari, } \\
\text { Uplistsikhe, Gelati, Bagrati, Vani Archaeological } \\
\text { Museum, Ushguli. }\end{array}$ & 12 days \\
\hline & & $\begin{array}{l}\text { Life of Georgian cities: Tbilisi, Kutaisi, Signagi and } \\
\text { Batumi Cultural monuments: Metekhi, Sioni, } \\
\text { Narikala, Anchiskhati, Sameba, National Museum, } \\
\text { Signaghi Ethnographic Museum, Bodbe Monastery } \\
\text { Complex, Tsinandali Wine Cellars, Jvar, } \\
\text { Svetitskhoveli, Bagrati, Gelati, Gonio Fortress, } \\
\text { Batumi Archaeological Garden, Batumi } \\
\text { Archaeological Garden Temple. }\end{array}$ & 9 days \\
\hline \multirow{5}{*}{$\begin{array}{l}\text { Tour operator } \\
\text { "Georgian Discovery } \\
\text { Tours" } \\
\text { http://www.gdt.ge }\end{array}$} & \multirow{5}{*}{$\begin{array}{l}\text { English, } \\
\text { Russian, } \\
\text { German, } \\
\text { Spanish }\end{array}$} & $\begin{array}{l}\text { Cities in caves and monasteries (Tbilisi, Borjomi, } \\
\text { Kutaisi). } \\
\text { Cultural monuments: Uplistsikhe, Safara, Vardzia, } \\
\text { Timotesubani, Gelati, Prometheus Cave, Sataplia, } \\
\text { Davit Gareji. }\end{array}$ & 5 days \\
\hline & & $\begin{array}{l}\text { All the beauty of Georgia (Tbilisi, Borjomi, Kutaisi, } \\
\text { Mestia, Batumi, Mtskheta, Telavi, Kvareli, Gurjaani, } \\
\text { Signaghi). } \\
\text { Cultural monuments: Vardzia, Bagrati, Gelati, } \\
\text { Ushguli, Jvari, Svetitskhoveli. Alaverdi, Al. } \\
\text { Chavchavadze House-Museum, Grammy, Davit } \\
\text { Gareji. }\end{array}$ & 11 days \\
\hline & & $\begin{array}{l}\text { Travel to the ancient region of Georgia (Tbilisi, } \\
\text { Khertvisi, Agara, Shoreti, Ota, Mirashkhani) Cultural } \\
\text { monuments: Tsunda, Vani boilers. }\end{array}$ & 7 days \\
\hline & & $\begin{array}{l}\text { Georgian castles and monasteries (Tbilisi, Mtskheta, } \\
\text { Borjomi, Signagi, Gurjaani). } \\
\text { Cultural monuments: Svetitskhoveli, Jvari, Shio- } \\
\text { Mgvime, Uplistsikhe, Vardzia, Davit Gareji, Shua } \\
\text { Mta, Alaverdi. }\end{array}$ & 6 days \\
\hline & & $\begin{array}{l}\text { Touch with history (Tbilisi, Mtskheta, } \\
\text { Stepantsminda, Gudauri, Gori, Bakuriani, Signagi, } \\
\text { Gurjaani, Tsinandali, Telavi). } \\
\text { Cultural monuments: Jvari, Svetitskhoveli, Ananuri } \\
\text { complex, Gergeti Trinity, Uplistsikhe, Davit Gareji, } \\
\text { Al. Chavchavadze House Museum, Alaverdi. }\end{array}$ & 6 days \\
\hline
\end{tabular}




\begin{tabular}{|c|c|c|c|}
\hline & & $\begin{array}{l}\text { The ancient beauties of Georgia (Tbilisi, Mtskheta, } \\
\text { Telavi, Tsinandali, Gurjaani, Signagi). } \\
\text { Cultural monuments: Tbilisi historical monuments, } \\
\text { Svetitskhoveli, Jvari, Bodbe Monastery Complex, Al. } \\
\text { Chavchavadze House-Museum. }\end{array}$ & 4 days \\
\hline \multirow{4}{*}{$\begin{array}{l}\text { Tour operator } \\
\text { "Concord Travel" } \\
\text { http://concordtravel.g } \\
\text { e }\end{array}$} & \multirow{4}{*}{$\begin{array}{l}\text { Georgian, } \\
\text { English, } \\
\text { Russian, } \\
\text { German, } \\
\text { French, } \\
\text { Japanese, } \\
\text { Polish, } \\
\text { Spanish, } \\
\text { Italian, } \\
\text { Lithuanian, } \\
\text { Chinese, } \\
\text { Arabic }\end{array}$} & $\begin{array}{l}\text { Caucasus Paradise (Tbilisi, Gori, Kutaisi, Zugdidi, } \\
\text { Nikortsmina, Signagi) Trinity Cathedral, Metekhi } \\
\text { Church, Old Tbilisi, Sulfur Baths, Narikala Fortress, } \\
\text { Sioni and Anchiskhati Church, Jvari Monastery, } \\
\text { Svetitskhoveli Cathedral, Ananuri Fortress, Joseph } \\
\text { Stalin House-Museum, Uplistsikhe, Trinity of } \\
\text { Gergeti, St. George of Bagrat Churches, Dadiani } \\
\text { Palace Ancient fortress-city fortress Goji, } \\
\text { Nikortsminda and Barakoni temples, Uba, Samtavisi, } \\
\text { Bodbe monastery, St. Nino's tomb, Alexander } \\
\text { Chavchavadze museum, Gremi, Shuamta, Ikalto } \\
\text { monastery and Alaverdi temple, Davit Gareji. }\end{array}$ & 15 days \\
\hline & & $\begin{array}{l}\text { Discover Georgia (Tbilisi, Telavi, Gori). } \\
\text { Cultural monuments: Trinity Cathedral, Metekhi } \\
\text { Church, Old Tbilisi, Sulfur Baths, Narikala Fortress, } \\
\text { Sioni and Anchiskhati Church, Bodbe Monastery } \\
\text { Complex, Al. Chavchavadze Palace, Alaverdi, } \\
\text { Gremi, New and Old Shuamti, Ikalto Monastery, } \\
\text { Jvari Monastery, Svetitskhoveli Temple), Ananuri } \\
\text { Fortress, Gergeti Trinity, Joseph Stalin House- } \\
\text { Museum, Uplistsikhe. }\end{array}$ & 11 days \\
\hline & & $\begin{array}{l}\text { Tour "Three Capitals" (Tbilisi, Mtskheta, Kutaisi, } \\
\text { Vani) Cult, monuments: Bagrati, Gelati, Sataplia, } \\
\text { Samtavisi, Jvari, Svetitskhoveli, Samtavro, Father } \\
\text { David Church, Narikala, Metekhi, Sioni, Sameba. }\end{array}$ & 6 days \\
\hline & & $\begin{array}{l}\text { Tour Sights of Georgia (Tbilisi, Telavi, Kazbegi, } \\
\text { Gori, Borjomi). } \\
\text { Cultural monuments: Trinity Cathedral, Metekhi } \\
\text { Church, Old Tbilisi, Sulfur Baths, Narikala Castle, } \\
\text { Sioni and Anchiskhati Church, Bodbe Monastery, St. } \\
\text { Nino's Tomb, Alexander Chavchavadze Museum in } \\
\text { Tsinandali. Wine tasting, trip to Telavi, visit Alaverdi } \\
\text { and travel to Khevi region, visit Mtskheta, Jvari } \\
\text { Monastery, Svetitskhoveli, Ananuri Fortress, visit } \\
\text { Gegreti Trinity Church, visit Sno Gorge, visit Joseph } \\
\text { Stalin Museum. Departure to Borjomi gorge, Vardzia. }\end{array}$ & 9 days \\
\hline $\begin{array}{l}\text { Tour operator } \\
\text { "Exotour" } \\
\text { www.exotour.travel }\end{array}$ & $\begin{array}{l}\text { Georgian, } \\
\text { English, } \\
\text { Russian }\end{array}$ & $\begin{array}{l}\text { Georgia - Classic Tour (Tbilisi, Mtskheta, Signaghi, } \\
\text { Gurjaani, Gori, Borjomi, Samtskhe-Javakheti, } \\
\text { Kutaisi, Batumi, Kazbegi, Bolnisi). } \\
\text { Abanotubani, Narikala Citadel, Metekhi, Sioni } \\
\text { Cathedral, Anchiskhati Basilica, Museum of Art of } \\
\text { Georgia, Mtskheta, Jvari Church, Svetitskhoveli, } \\
\text { Signagi, museum of Niko Pirosmani, the church of } \\
\text { All Saints, Tsinandali, Alaverdi Cathedral, the } \\
\text { monastery of Ikalto, Shuamta, Gori fortress walls, } \\
\text { Uplistsikhe, Bagrati Church, Gelati Monastery } \\
\text { Complex, Sataplia reserve, Batumi Botanical } \\
\text { Gardens, Borjomi Park, Saphara monastery, } \\
\text { Khertvisi Fortress, Vardzia, Ananuri castle, Gergeti } \\
\text { Trinity Church, Bolnisi Sioni Church, Dmanisi. }\end{array}$ & 10 days \\
\hline
\end{tabular}




\begin{tabular}{|l|l|l|l|}
\hline Tour Company & & Tbilisi-Anchiskhati church, Sioni cathedral, Narikala & \\
"Next Travel" & castle, Sameba cathedral, Father David's church, & \\
http://www.nexttrave & English & Tbilisi State Museum, Anchiskhati church, Sioni & 1 day \\
l.ge & & Cathedral Church, Narikala castle, Sameba Cathedral & 1 Cand \\
& & Church, Mamadaviti church and pantheon, Tbilisi & \\
& National Museum. & \\
\hline
\end{tabular}

Note. Authors, according to the content analyses of the web-sites.

The fact that tours with cultural tourism activities are really important is also demonstrated in Diagram 1, which shows statistics for 2018 and 2019.

Diagram 1. Popular Activities of 2018 and 2019 years

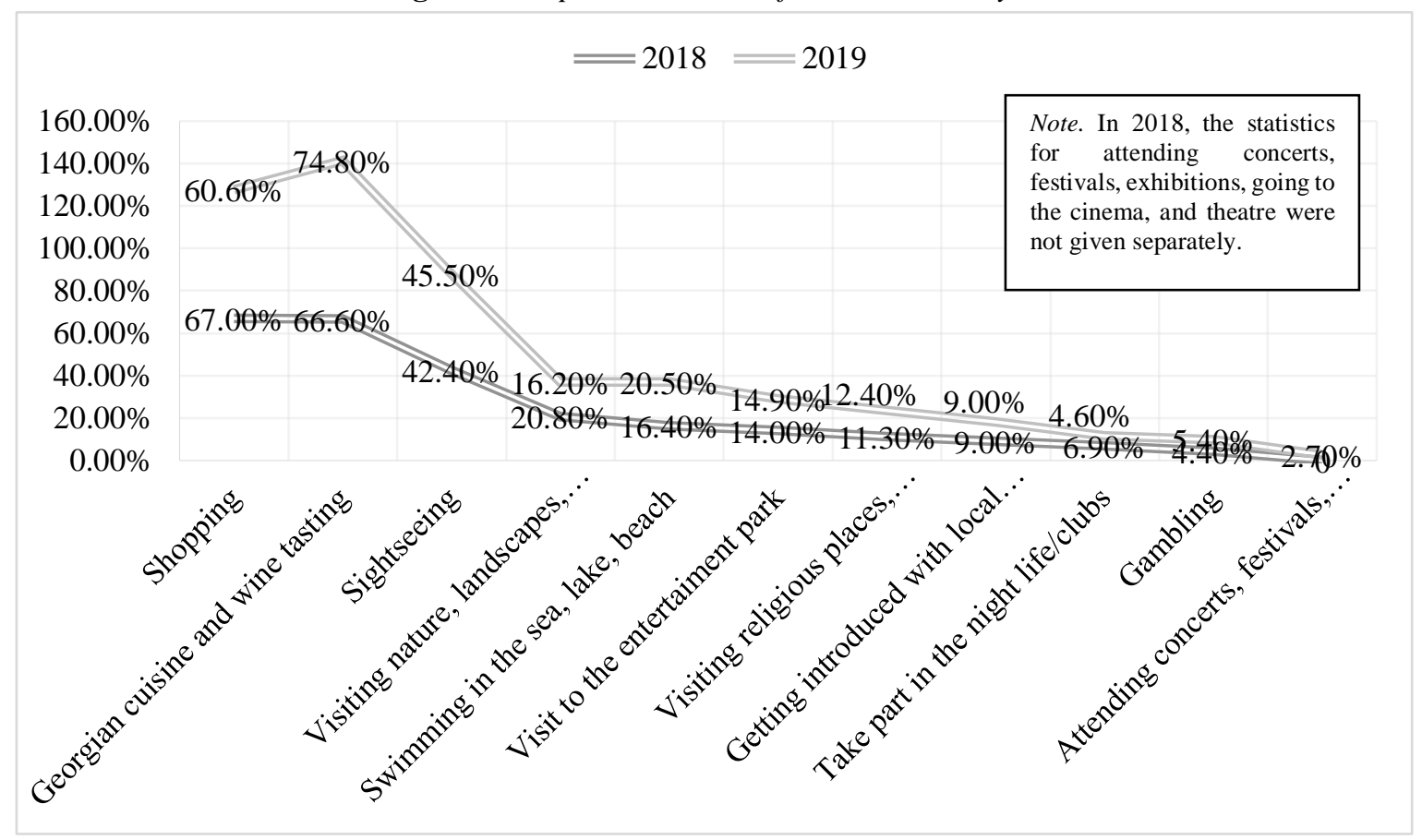

Note. Authors, according to National Statistics Office of Georgia (Inbound Tourism Statistics, National Statistics Office of Georgia., n.d.)

According to the statistics of tourists' interests by nationality of 2019 (see Table 6), people from various countries have different interests. Thus, after the market study, tour companies should have the right focus. These countries were chosen for the reason that they are neighbors with Georgia, and so their interest in travelling here is huge. 
Table 6. Tourists' Activities in 2019, by nationality

\begin{tabular}{|l|c|c|c|c|c|c|c|}
\hline \multicolumn{1}{|c|}{ Activity } & Azerbaijan & Turkey & Russia & Armenia & $\begin{array}{c}\text { Central } \\
\text { and } \\
\text { Eastern } \\
\text { Europe }\end{array}$ & $\begin{array}{c}\text { Other } \\
\text { European } \\
\text { countries }\end{array}$ & $\begin{array}{c}\text { Other } \\
\text { Countries }\end{array}$ \\
\hline Tasting of local cuisine and wine & $68.2 \%$ & $58.1 \%$ & $88.1 \%$ & $70.2 \%$ & $86.1 \%$ & $85.2 \%$ & $77.3 \%$ \\
\hline Shopping & $58.8 \%$ & $42.3 \%$ & $66.8 \%$ & $83.2 \%$ & $55.9 \%$ & $50.5 \%$ & $55.8 \%$ \\
\hline $\begin{array}{l}\text { Visiting sights, cultural and } \\
\text { historical heritage monuments, } \\
\text { and museums }\end{array}$ & $28.9 \%$ & $54.3 \%$ & $49.8 \%$ & $4.4 \%$ & $72.1 \%$ & $78.8 \%$ & $81.3 \%$ \\
\hline Visiting entertainment park & $14.2 \%$ & $11.3 \%$ & $15.4 \%$ & $7.2 \%$ & $19.7 \%$ & $20.2 \%$ & $28.1 \%$ \\
\hline $\begin{array}{l}\text { Going to the seaside, lake, river, } \\
\text { swimming, and going to the beach }\end{array}$ & $12.9 \%$ & $35.3 \%$ & $19.2 \%$ & $9.3 \%$ & $35.8 \%$ & $24.2 \%$ & $17.6 \%$ \\
\hline $\begin{array}{l}\text { Visiting nature, landscapes, } \\
\text { reserves }\end{array}$ & $11.4 \%$ & $17.5 \%$ & $15.1 \%$ & $2.3 \%$ & $24.4 \%$ & $30.6 \%$ & $33.9 \%$ \\
\hline Nightlife, clubs & $4.4 \%$ & $7.4 \%$ & $1.7 \%$ & $3.6 \%$ & $5.5 \%$ & $5.6 \%$ & $7.4 \%$ \\
\hline Visiting religious places, churches & $2.6 \%$ & $11.7 \%$ & $20.4 \%$ & $10.4 \%$ & $16.9 \%$ & $17.6 \%$ & $12.5 \%$ \\
\hline Gambling & $2.4 \%$ & $23.0 \%$ & $0.8 \%$ & $0.1 \%$ & $1.2 \%$ & $5.8 \%$ & $3.5 \%$ \\
\hline $\begin{array}{l}\text { Participation in agricultural } \\
\text { activities }\end{array}$ & $1.7 \%$ & $0.1 \%$ & $0.5 \%$ & $0.0 \%$ & $2.5 \%$ & $1.7 \%$ & $1.4 \%$ \\
\hline $\begin{array}{l}\text { Getting introduced to local art, } \\
\text { culture, language, history }\end{array}$ & $1.50 \%$ & $3.8 \%$ & $8.6 \%$ & $0.1 \%$ & $17.9 \%$ & $32.7 \%$ & $23.7 \%$ \\
\hline
\end{tabular}

Note. Authors, according to the National Statistics Office of Georgia (Inbound Tourism

Statistics, National Statistics Office of Georgia., n.d.)

Diagram 1 and Table 7 demonstrate getting introduced to art, culture and history, as well as sightseeing, tasting wine, and local cuisine. Thus, this part of cultural tourism is very popular, but it depends also on the reason for travelling. This is also proven by the activities of tourists within neighboring countries as they often cross our borders (e.g., Armenia). Also, the purpose of travelling appears to be for shopping and local food, not sightseeing or visiting religious places of interest. It will be also interesting to discuss the expenses of tourists within these two years (see Table 7).

Table 7. Structure of Tourists Expenses in 2018 and 2019

\begin{tabular}{|c|c|c|c|c|}
\hline Components of Expenses & $\begin{array}{c}\text { The sum of whole } \\
\text { touristic expenses } \\
\text { incurred by visitors in } \\
\mathbf{2 0 1 8} \text { in Gel }\end{array}$ & $\begin{array}{c}\text { Share in } \\
\text { total } \\
\text { expense }\end{array}$ & $\begin{array}{c}\text { The sum of whole } \\
\text { touristic expenses } \\
\text { incurred by visitors in } \\
\mathbf{2 0 1 9} \text { Gel }\end{array}$ & $\begin{array}{c}\text { Share in } \\
\text { total } \\
\text { expense }\end{array}$ \\
\hline Food and Beverages & $\mathbf{2 , 2 6 6 , 8 8 1 , 1 3 3}$ & $\mathbf{2 8 . 6 \%}$ & $\mathbf{2 , 3 4 3 , 4 2 1 , 2 7 9}$ & $\mathbf{2 7 . 5 \%}$ \\
\hline Accommodation & $1,854,514,224$ & $23.4 \%$ & $2,021,228,953$ & $23.7 \%$ \\
\hline $\begin{array}{c}\text { Recreation, cultural and } \\
\text { sports activities }\end{array}$ & $\mathbf{1 , 4 3 4 , 7 0 5 , 2 3 2}$ & $\mathbf{1 8 . 1 \%}$ & $\mathbf{1 , 5 2 8 , 7 0 5 , 8 8 8}$ & $\mathbf{1 8 . 0 \%}$ \\
\hline Shopping & $1,074,094,320$ & $13.6 \%$ & $1,800,271,650$ & $21.2 \%$ \\
\hline Local Transport & $560,769,313$ & $7.1 \%$ & $644,544,830$ & $7.6 \%$ \\
\hline Other expenses & $726,539,907$ & $9.2 \%$ & $173,362,328$ & $2.0 \%$ \\
\hline The sum of touristic expenses in 2018 - 7 917 504 128 GEL & & \\
\hline The sum of touristic expenses in 2019 - 8511 534 927 GEL & & \\
\hline The average of per visitor's expense in 2018 - 1 099 GEL \\
\hline The average of per visitor's expense in 2019 - 1 102 GEL \\
\hline
\end{tabular}

Note. Authors, according to the International Visitors Survey Report of the National

Tourism Administration 2018 and 2019 
As demonstrated in Table 7, recreation, cultural and sports activities were in third place in 2018 and fourth place in 2019. However, its share in the total expenses has not changed much from $18.1 \%$ to $18 \%$. As for infrastructure, e.g., ticketing systems are not still well organized. Also, income is less than it should be because nowadays tourists can visit places and do not spend money besides transport. Also, according to the Tax Code of Georgia, income received from the sale of religious items is exempted from taxes. As a result, direct profit or expenses that may be received from a tourist cannot be counted.

In this current time, Georgia is facing challenges and is way behind developed countries. Since Georgia is a small country, problems appear to be more serious and important in the context of sustainability. This is because in the case of mass tourism, it will be impossible to control the flows. Therefore, attention should be paid to "tourism carrying capacity", which can be assessed through many factors. "Carrying Capacity" in the case of cultural sightseeing is an indicator, which should provide a high level of visitor satisfaction in the conditions of minimal impact on resources. This should be within the appropriate limits of the use of the area. The violating of the principle "carrying capacity" harms tourism development and causes the violation of the principles of sustainable development.

Nowadays, as the world is facing an unprecedented global health, social, and economic emergency due to the COVID19 pandemic, it is very important that the sector adopts a feasible situation. Current tourism challenges that bring together experts and tourism professionals offer different provisions together with UNWTO. They assume it will cause a significant diversification of products and will promote some of the trendy types considering the new status quo. Several trends will gain popularity as per their content and the possibility to provide social distancing and safe health standards. Georgia can offer diverse experience and emotions including: Cultural: visiting historical, architectural and religious sites; Wine: visiting wine-related sites including wineries, family-run wine cellars and related cultural attractions; rural farms and boutique Chateaus; Adventure: visiting national parks and Great Caucasus mountains; Holiday, recreation, and leisure: weekends tour (Koblianidze \& Tabidze, 2020).

The main challenge faced by the government is creating a mechanism that can avoid the spread of COVID-19 by visitors. In this case, a good example is seen in Singapore. Here, an SG clean certificate is created and if the companies engaged in the tourism business want to get it, they have to meet the requirements of 7 different standards (Koblianidze \& Tabidze, 2020).

After studying the reason for travelling to those regions, the popularity of cultural tourism shows that the factors which are important for them while travelling was obtained using a quantitative research (period: 15-31 August). 
200 people were interviewed, consisting of $68 \%$ women and $32 \%$ men. The research was carried out based on the hypothesis that during the pandemic, local people prefer to travel to Georgia on cultural tours.

The results showed that $72 \%$ (144 people) of Georgians always try to visit cultural sightseeing when they go to the sea or to the mountains to rest. $82 \%$ of people try to visit cultural places of interest at the weekend and the factors which they are paying attention to while travelling is given below in Diagram 2.

Diagram 2. Factors influencing travelling on Cultural Tour

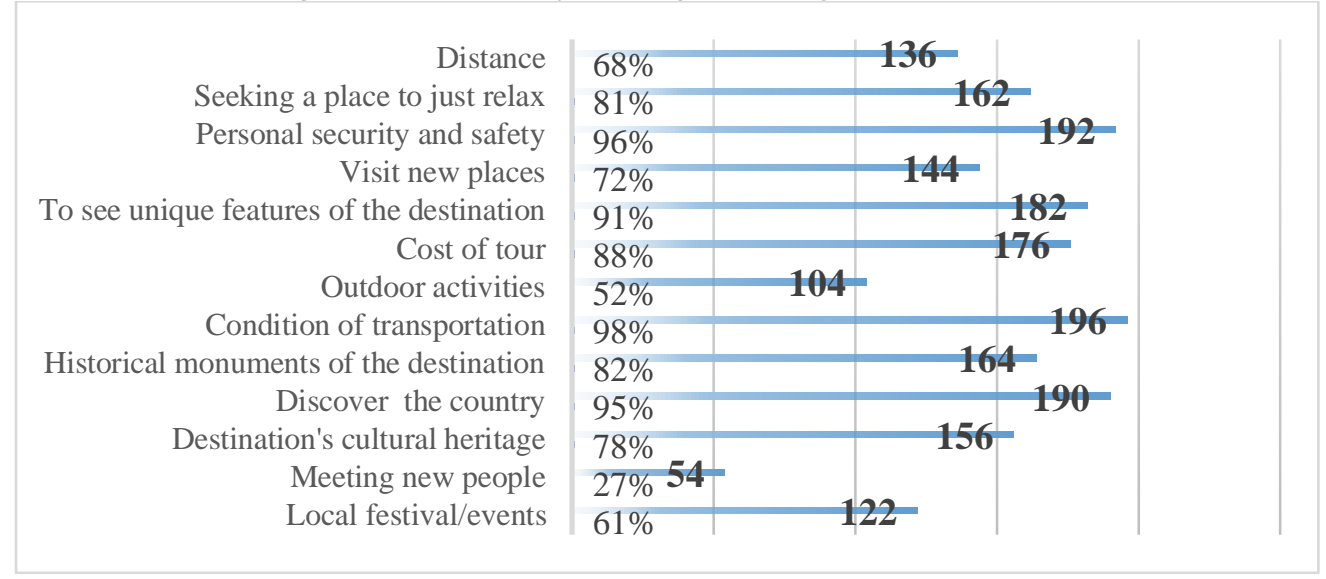

Note. Authors, according to the research

Based on the question of how much they spend while travelling on a cultural tour, the results were as follows:

Diagram 3. Amount spent daily

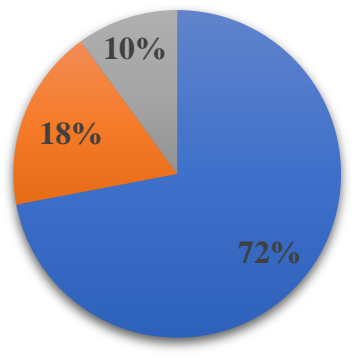

-0-50 GEL $\square$ 50-100GEL $\square$ more than $100 \mathrm{GEL}$

Note. Authors, according to the research 
Diagram 4. Source of information

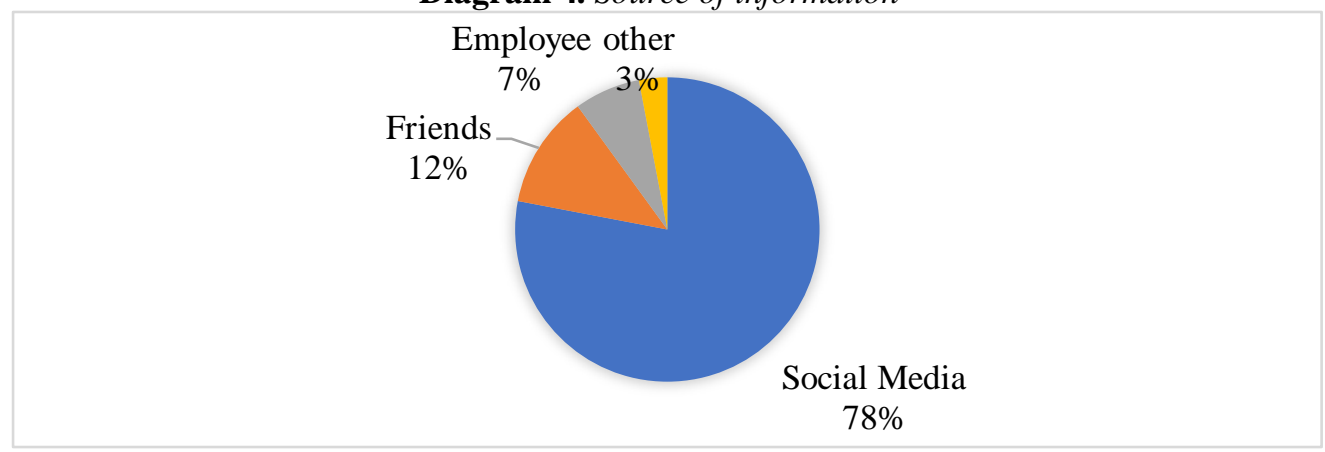

Note. Authors, according to the research

The content analysis method revealed studied information about cultural tours on the social network. It showed that the price of the tour is up to 120GEL (depending on the distance, food, activities) per day, and this price includes transport (sometimes they do not need it) and guide. While the pandemic government of Georgia has created an anti-crisis plan (Tourism Activation - Anticrisis Plan, n.d.) to support the local tourism and tour companies, cheap price is also caused by these tax regulations. However, the cheap price in some cases indicates poor quality of the transport which has a negative influence on people's safety. Therefore, quality control mechanisms appear to be the most important challenge that must be regulated. An important role for marketing activities is the use of social media. This is because $78 \%$ (156 people) get information from it. Social media gives an opportunity to get in touch with potential clients directly, organize tours, make events, invite them, and share photos. However, on the international level, not everyone uses social media. As a result, websites, with a well-managed booking system, are also very important for cultural tourism development.

\section{Conclusion}

The findings of this study indicate that according to the discussed recommendations of EU, Georgia still has active subjects. This shows that the policymakers or public organizations still have some work to do. Also, the main principle of cultural tourism development should include sustainability and the maintenance of identity.

The research revealed that the existence of Cultural Routes of the Council of Europe and the cultural heritage in the UNESCO World Heritage List is a precondition for popularization in the international tourism market. Nonetheless, without the necessary infrastructure and sustainable development strategies, the country may face cultural heritage damage and loss, which does not meet sustainable development requirements (e.g., mass flow mechanisms). Conversely, this will cause problems to conservation. 
According to the study, the potential of Georgia is not used completely by Georgian tour companies and the main focus is on the UNESCO heritage list. According to the content analysis of the websites, the tour companies in Georgia should follow the examples of successful developed countries and create websites that will help tourists so as to organize more suitable tours for them (depending on their interests). Another important subject which should be managed is the calendar of cultural events. Thus, this will give more opportunities to tourists as well as to tours companies to plan tours and holidays on behalf of the important cultural events, especially in regions. In this case, Destination Management Organizations can have a positive impact, which is already created in some regions. Also, the local events based on traditions, culture, and identity have the opportunity to attract more tourist and reduce the seasonality factor, which is very important for people who are employed in the tourism business.

Modern technologies give new opportunities to ticketing systems, which makes travelling more flexible. Therefore, this will have a significant positive impact if tour guides can be managed with special cards or mobile applications to run the queues and if they have the opportunity to enter the museum or other places of interest with pre-purchased e-tickets. This will give the motivation to tourists to visit places of interests with tour guides rather than organize such tours on their own. Nowadays, in some places in Georgia (especially in Tbilisi), tickets are available to buy online but only in several cases. This kind of electronic system shows statistics about the popular tour companies, guides, museums, etc.

The quantitative research proved and supported the hypothesis that during the pandemic, local people prefer to travel to Georgia on cultural tours. The factors, which local tourists have mentioned, show that cultural tourism has a huge opportunity between locals. Also, tour companies should take note of the aspects which have a significant influence on their decision making. Subsequently, these factors are common for any kind of tourist and, in some cases, it appears to play an important role. Thus, it should be eliminated as soon as possible to become competitive at both local and global levels. The global pandemic gave new opportunities to tour companies to offer various types of cultural tours to tourists combined with wine tours and tours with agritourism activities. Besides, the borders are still closed and the pandemic gave a hand to new challenges and opportunities, which will have a positive impact on cultural tourism development. 


\section{References:}

1. Academic Press of Georgia. (n.d.). Retrieved October 2, 2020, from http://apgeorgia.com/

2. Crafting Europe (2020). Retrieved from https://www.craftingeurope.net/the-project/

3. Creative Georgia. Culture Strategy of Georgia 2025. (n.d.). Retrieved September 20, 2020, from http://creativegeorgia.ge/Publications/Strategic_Documents/saqartvel os-kulturis-strategia-2025.aspx?lang=en-US

4. Cultural Heritage Policy. Council of Europe. (n.d.). Retrieved October 6, 2020, from https://www.coe.int/en/web/herein-system/georgia

5. Discount Week. National Tourism Administration. (n.d.). Retrieved September 2020, from https://gnta.ge/ge

6. Europa Nostra, European Heritage Awards Ceremony 2019. (n.d.). Retrieved August 1, 2020, from http://www.europeanheritageawards.eu/programme/

7. Europa Nostra, Heritage Crafts Initiative for Georgia. (n.d.). Retrieved from http://www.europeanheritageawards.eu/winners/heritage-craftsinitiative-georgia/

8. Following Alexandre Dumas. Cultural Routes of Georgia. (n.d.). Retrieved September 1, 2020, from http://culturalroutes.gov.ge/Routes/saqartvelos-kulturulimarshrutebi/Following-Alexandre-Dumas.aspx

9. From Capital to Capital. Cultural Routes of Georgia. (n.d.). Retrieved September 2, 2020, from http://culturalroutes.gov.ge/Routes/saqartvelos-kulturulimarshrutebi/dedaqalaqidan-dedaqalaqamde.aspx

10. Gaccgeorgia (n.d.). Retrieved October 2, 2020, from https://www.gaccgeorgia.org/FrameCraft.html

11. Georgian National Tourism Administration (2020). Tbilisi, Georgia. Retrieved September 7, 2020, from https://gnta.ge

12. German Settlements. Cultural Routes of Georgia. (n.d.). Retrieved August 31, 2020, from

http://culturalroutes.gov.ge/Routes/saqartvelos-kulturulimarshrutebi/germanuli-dasakhlebebis-marshruti-(1).aspx

13. Goeldner, C. R., \& Ritchie, J. R. (2009). Tourism: Principles, Practices, Philosophies. John Wiley \& Sons, Inc.

14. Hargrove, C. (2014). Cultural Tourism: Attracting Visitors And Their Spending. Americans for Arts.

15. Hewison, R. (1987). The heritage Industry: Britain in a climate of decline. London: Methuen. 
16. Inbound Tourism Statistics. National Statistics office of Georgia. (n.d.). Retrieved from https://www.geostat.ge/en

17. Intangible Cultural Heritage. (n.d.). Retrieved October 2, 2020, from https://unesco.ge/?page_id=568\&lang=en

18. Jittangwattana, B. (2005). Sustainable tourism development. Bangkok: Press \& Design.

19. Koblianidze, T., \& Tabidze, T. (2020). Challenges of Covid 19 and new opportunities for Georgian tourism. Georgian Technical University.

20. Koblianidze, T., \& Tabidze, T. (2020). Future Tourism Trends After Post - Pandemic Period. Proceedings of Materials (pp. 272-276). Tbilisi: Iv.Javakhishvili State University, Paata Gugugshvili Institute of Economics.

21. Kotollaku, M., \& Margariti, M. M. (2015). CULTURAL TOURISM IN GJIROKASTRA. European Scientific Journal, Volume 11.No.14

22. Loan and Leasing Co-financing Program, Government your partner. (n.d.). Retrieved 5 September, 2020, from https://programs.gov.ge

23. Richards, G. (2001). Cultural attractions and European tourism. Wallingford: CABI.

24. Richards, G. (2018). Cultural tourism: A review of recent research and trends. Journal of Hospitality and Tourism Management, 12-21.

25. Smith, M. (2003). Issue in cultural tourism studies. London: Routledge.

26. St. Andrew's Path. Cultural Routes of Georgia. (n.d.). Retrieved September 1, 2020, from

http://culturalroutes.gov.ge/Routes/saqartvelos-kulturulimarshrutebi/cm-andria-pirvelcodebulis-gza.aspx

27. Sustainable Cultural Tourism. European Comission (2018). Retrieved August 15, 2020, from https://europa.eu/culturalheritage/sites/eych/files/sustainable-cultural-tourismrecommendations_en5097.pdf?token=PsePI9T4

28. Szivas, D. E. (2019). Cultural Routes National Country Mapping.

29. Tourism Activation - Anticrisis Plan. (n.d.). Retrieved October 2, 2020, from

http://www.economy.ge/uploads/files/2017/news/2020/final_tourism _presentation.pdf

30. Tourism Organization. (n.d.). Retrieved October 1, 2020 , from https://to.edu.ge/trainings/incoming-tourism/

31. Tourism Strategy Reform Overview. (n.d.). Retrieved from https://reformeter.isetpi.ge/system/reform_survey_reports/24/en/Report_I.pdf 
32. Trainings and training courses, National Tourism Administration. (n.d.). Retrieved September 5, 2020, from https://programs.gov.ge

33. UNESCO. (n.d.). Properties inscribed on the World Heritage List. Retrieved August 15, 2020, from https://whc.unesco.org/en/statesparties/ge

34. UNWTO (2018). Tourism and Culture Synergies. Retrieved August 15,2020 , from https://www.e-unwto.org/doi/epdf/10.18111/9789284418978

35. Vujović, V. (2018). Diversification of Cultural Tourism: Development Trend or the Beginning of Culture, Heritage And Tourism Development. SITCON 2018. 